\title{
PATHOGENICITY OF A BOVINE VIRAL DIARRHOEA VIRUS STRAIN IN PREGNANT SOWS: SHORT COMMUNICATION
}

\author{
G. KULCSÁR ${ }^{1 *}$, P. SOÓs ${ }^{2}$, L. KUCSERA ${ }^{1}$, R. GLÁVITS ${ }^{3}$ and V. PÁLFI ${ }^{3}$ \\ ${ }^{1}$ State Control Institute for Veterinary Biologicals, Drugs and Feeds, H-1415 Budapest \\ 10, P.O. Box 318, Hungary; ${ }^{2}$ Department of Microbiology and Infectious Diseases, \\ University of Veterinary Science, Budapest, Hungary; ${ }^{3}$ Central Veterinary Institute, \\ Budapest, Hungary
}

(Received February 25, 2000; accepted May 3, 2000)

\begin{abstract}
The biological properties of bovine viral diarrhoea virus (BVDV) strain Oregon $\mathrm{C} 24 \mathrm{~V}$ were studied after intranasal and subcutaneous infection of pregnant sows. This virus strain is widely used in Hungary for immunising cattle against bovine viral diarrhoea (BVD). Based upon the results of the clinical, gross pathological, histopathological and virological examinations it can be established that the given strain caused asymptomatic infection and serological conversion in sows that were in the second third of gestation. The virus caused clinically apparent disease in some of the piglets born at term, which indicates that it had crossed the placenta. More than half (57\%) of the live-born piglets died within 60 days of birth. The sows and their progeny did not shed the virus. BVDV infection has great differential diagnostic importance in pigs, as classical swine fever (CSF) virus strains of reduced virulence cause similar clinical symptoms and gross and histopathological changes.
\end{abstract}

Key words: Pestivirus, classical swine fever virus, bovine viral diarrhoea virus, pregnant sow, fetopathic effect

Bovine viral diarrhoea virus (BVDV) belongs to the Pestivirus genus of the Flaviviridae family, together with classical swine fever virus (CSFV) and border disease virus (BDV) of sheep.

The infection of pigs with BVDV under natural conditions was first $\mathrm{d}$ escribed in Australia (Flynn and Jones, 1964), then it was reported from the Net herlands, Germany, France, Great Britain, Denmark and the United States. Ser ological surveys indicate that the prevalence of infection in pig herds varies $b$ etween 3 and $40 \%$, depending on the age of the animals and the degree of their contact with cattle (Stewart et al., 1971; Carbrey et al., 1976; Terpstra and Wensvoort, 1988; Vannier and Leforban, 1992). Cattle shedding the virus serve as the main source of infection, but different live virus vaccines contaminated with BVDV may also transmit the virus. In 1973, the virus was successfully is o-

*E-mail: kulcsar@oai.hu; Fax: +36 (1) 262-2839 
lated from swine (Fernelius et al., 1973). Clinical symptoms usually do not d evelop after the infection, but in pregnant sows occasionally a fetopathic effect may occur. The newborn piglets are weak, retarded in growth and show dia rrhoea and respiratory symptoms. Affected animals usually die within a few weeks (Carbrey et al., 1976; Terpstra and Wensvoort, 1991; Liess and Moennig, 1990; Terpstra and Wensvoort, 1991; Paton and Done, 1994). The condition could not be consistently reproduced by the experimental infection of pregnant sows (Fernelius et al., 1973; Mengeling, 1988; Leforban et al., 1990). The co nsequences of infection depend on the infective virus strain and the stage of ge station of the sow (Vannier and Leforban, 1992). The NADL strain did not cause disease in piglets, while the Singer strain adapted to cell lines of porcine origin were found to be severely fetopathic (Mengeling, 1988; Leforban et al., 1990). The Oregon $\mathrm{C} 24 \mathrm{~V}$ strain induced an antibody response in piglets, which pr otected them against CSFV infection (Snowdon and French, 1968). Other authors (Simonyi and Bíró, 1967) found that the antibodies elicited by the Oregon C24V strain did not protect the animals against CSFV infection. The most severe $\mathrm{r}$ eproductive symptoms develop if the sows are infected between day 25 and 41 of gestation (Mengeling, 1988; Leforban et al., 1990).

Due to the close antigenic relatedness of pestiviruses, BVDV gives crossreaction with CSFV in conventional serological tests. A further diagnostic diff iculty results from the fact that by clinicopathological examinations the disease produced by CSFV strains of reduced virulence cannot be distinguished from the condition caused by BVDV (Loken, 1995).

In this study, the clinical signs, gross and histopathological changes and the kinetics of virus shedding and the immune response were studied in pregnant sows experimentally infected with BVDV by the intranasal and subcutaneous route.

\section{Materials and methods}

Four Hungarian Large White sows being in the second third of gestation (days 54-73) and free from virus-neutralising antibodies to CSFV and BVDV were used in the experiment. Two sows were inoculated with BVDV strain Oregon $\mathrm{C} 24 \mathrm{~V}$ : one of them received $2000 \mathrm{TCID}_{50}$ virus intranasally while the other one subcutaneously. Two sows were kept isolated as uninfected negative co ntrols.

The animals were observed daily for clinical signs and their rectal te $\mathrm{m}$ perature was recorded. After infection, nasal and rectal swabs as well as urine and blood samples were taken from the sows and the piglets weekly over a $p$ eriod of 16 weeks.

The animals that died during the experiment and those killed in week 16 after experimental infection were examined for gross pathological changes, and organ samples (spleen, lungs, kidney, brain, tonsil, mesenteric and submandib u- 
lar lymph node) were collected from them for histopathological examination. The samples were fixed in $10 \%$ neutral buffered formalin, embedded in paraffin, and the sections were stained with haematoxylin and eosin.

Detection of antibodies to BVDV virus in the serum was performed by the virus neutralisation test, in secondary calf testicle cell cultures, using the Oregon C24V strain.

Virus isolation was done in secondary calf testicle cell cultures.

\section{Results and discussion}

Both infected sows remained clinically healthy throughout the period of o bservation, and did not shed the virus. From postinfection week 4 up to the end of the experiment, virus-neutralising antibodies to BVDV could be detected in a titre of 1:80-1:240 in both animals. Gross pathological changes were not found in the sows killed at the end of the experiment. The histopathological findings included focal interstitial nephritis and follicular hyperplasia in the lymphoid o rgans.

The intranasally infected sow delivered 13 live piglets on day 115 of ge station. In that litter, eight piglets were weak and had ruffled hair coat and showed splayleg, trembling, myoclonus, diarrhoea, and fever $\left(40.2-40.9^{\circ} \mathrm{C}\right)$. The affected piglets died within 40 days of birth. The subcutaneously infected sow d elivered eight live-born and one stillborn fetuses on day 113 of gestation. Four out of the live-born fetuses fell ill, showing clinical signs similar to those described above, and died within 60 days of birth. Attempts to isolate virus from the piglets failed. The serum of all piglets contained antibodies to BVDV in titres gradually decreasing over time. In the 8th week of life, the piglets of the intranasally i nfected sow no longer had serum antibodies in titres detectable by the VN test. In the piglets of the subcutaneously infected sow the antibodies had a higher baseline titre (1:240) and persisted longer: they were still detectable in week 9 after birth.

In the live-born piglets that subsequently died there were petechial hae morrhages at the predilection sites and lymphoid hyperplasia in the spleen and lymph nodes. Three dead piglets had interstitial pneumonia and acute gastroe nteritis. The clinically healthy piglets euthanised at the end of the experiments were free from gross and histopathological changes.

The negative control sows and their offspring remained healthy throug hout the experiment.

In this study, sows being in the second third of gestation were successfully infected by the subcutaneous and intranasal route with a pestivirus of ruminant or igin, strain Oregon C24V used also for vaccine production. Successful infection was confirmed serologically. The virus crossed the placenta and caused clinically apparent disease in the progeny. Perinatal mortality was substantial: $57 \%$ of the live-born piglets died. The sows and their piglets did not shed the virus, which o b- 
servation is consistent with the findings of Leforban et al. (1992). The decreasing antibody titre suggests that the piglets did not develop active immunity; rather, a ntibodies of maternal origin were detected in their s erum.

The clinical symptoms and gross pathological changes found in the piglets are consistent with the symptoms and lesions produced by CSFV strains of $\mathrm{r}$ educed virulence. This fact underscores the differential diagnostic importance of BVDV infection.

\section{References}

Carbrey, E. A., Stewart, W. C., Kresse, J. I. and Snyder, M. L. (1976): Natural infection of pigs with bovine viral diarrhea virus and its differential diagnosis from hog cholera. J. Am. Vet. Med. Assoc. 169, 1217-1219.

Fernelius, A. L., Amtower, W. C., Lambert, G., McClurkin, A. W. and Matthews, P. J. (1973): Bovine viral diarrhoea virus in swine: Characteristics of virus recovered from naturally and experimentally infected swine. Can. J. Comp. Med. 37, 13-20.

Flynn, D. M. and Jones, T. E. (1964): The position regarding swine fever in Victoria. Aust. Vet. J. 40, 131-137.

Leforban, Y., Vannier, P. and Cariolet, R. (1990): Pathogenicity of border disease and bovine viral diarrhoea viruses for pigs: Experimental study on the vertical and horizontal transmission of the viruses. Proc. 11th Int. Cong. Pig Vet. Soc., Lausanne, p. 204.

Leforban, Y., Vannier, P. and Cariolet, R. (1992): Protection of piglets born from ruminant pestivirus experimentally infected sows, and their contacts, to the challenge with hog cholera virus. Ann. Rech. Vet. 23, 73-82.

Liess, B. and Moennig, V. (1990): Ruminant pestivirus infection in pigs. Rev. Sci. Tech. Off. Int. Epizoot. 9, 151-161.

Loken, T. (1995): Ruminant pestivirus infections in animals other than cattle and sheep. In: Baker, J. C. and Houe, H. (eds) The Veterinary Clinics of North America: Food Animal Practice. Bovine Viral Diarrhoea Virus. W. B. Saunders, Philadelphia, pp. 597-614.

Mengeling, W. L. (1988): The possible role of bovine viral diarrhoea virus in maternal reproductive failure of swine. Proc. 10th Int. Cong. Pig Vet. Soc., Rio de Janeiro, p. 228.

Paton, D. J. and Done, S. H. (1994): Congenital infection of pigs with ruminant-type pestiviruses. J. Comp. Pathol. 111, 151-163.

Simonyi, E. and Bíró, J. (1967): Immunization experiments against hog cholera with the bovine viral diarrhoea strain Oregon C24V. Acta Vet. Acad. Sci. Hung. 17, 55-61.

Snowdon, W. A. and French, E. L. (1968): The bovine mucosal disease - swine fever virus complex in pigs. Aust. Vet. J. 44, 179-184.

Stewart, W. C., Varbrey, E. A., Jenney, E. W., Brown, C. L. and Kresse, J. I. (1971): Bovine viral diarrhea infection in pigs. J. Am. Vet. Med. Assoc. 159, 1556-1563.

Terpstra, C. and Wensvoort, G. (1988): Natural infection of pigs with bovine viral diarrhoea virus associated with signs resembling swine fever. Res. Vet. Sci. 45, 137-142.

Terpstra, C. and Wensvoort, G. (1991): Bovine viral diarrhea virus infection in swine. Tijdschr. Diergeneeskd. 116, 943-948.

Vannier, P. and Leforban, Y. (1992): Bovine viral diarrhoea and border disease. In: Leman, A. D., Straw, B. E., Mengeling, W. L., D'Allaire, S. and Taylor, D. J. (eds) Diseases of Swine. Iowa State Univ. Press, Ames, Iowa, USA, pp. 242-246. 